\title{
LOCAL HEPATIC IMMUNE RESPONSE IN RATS DURING PRIMARY INFECTION WITH FASCIOLA HEPATICA
}

\author{
TLIBA O.*, SIBILLE P.*, BOULARD C.* \& CHAUVIN A.**
}

\begin{abstract}
Summary :
The distribution of lymphocyte subpopulations $\left(T C D 4^{+}, \mathrm{TCD}^{+}\right.$ $\mathrm{TCD} 3^{+}$and $\mathrm{gg}^{+}$cells), macrophages and eosinophils were analysed in the inflammatory infiltrates associated with hepatic lesions and in hepatic lymph nodes (HLN) from rats experimentally infected with $F$. hepatica and necropsied 1, 2, 3, 4, 6 and 8 week post infection (WPI). We also investigated the fixation of immunoglobulin isotypes on migrating flukes in the liver. As early as IWPI, portal tract areas surrounding migratory tunnels were infiltrated with immune and inflammatory cells. The dominant cells were eosinophils and to lesser extent, macrophages and lymphocytes (TCD4+, TCD8 ${ }^{+}$and B). Most of the inflammatory and immune cells reached the posterior part of flukes, whereas in front of the parasites these cells were fewer in number. Except for eosinophils, no immune cells penetrated through granuloma consisting of hepatic necrotic cells. As early as IWPI, IgM could be detected in the liver, and to a lesser extent $\lg A, \lg G_{2 a}$ and $\lg G_{2 b}$. At $2 W P I, \lg E$ and $\lg G_{1}$ began being detected. $\lg G_{2 c}$ was detectable at $3 \mathrm{WPI}$. In HLN, we observed numerous microscopic follicles in the cortical zone with proliferation of germinal centres and medullary cords. The protective role of infiltrating cell populations and immunoglobulin isotypes and possible mechanisms of immune evasion by the parasite are discussed.
\end{abstract}

KEY WORDS : Fasciola hepatica, rat, lymphocytes, hepatic parenchyma, hepatic lymph node, immunohistochemistry, ADCC.

MOTS CLÉS : Fasciola hepatica, rat, lymphocytes, parenchyme hépatique, ganglions lymphatiques hépatiques, immunohistochimie, ADCC.

\section{INTRODUCTION}

F Tasciola bepatica is a liver fluke which causes huge economic losses in animal production (sheep and cattle). This parasite can affect a wide range of both domestic and wild species as well as human beings. The immune response and resistance to infection or re-infection are quite variable in different

\footnotetext{
* Unité d'Immunopathologie des Maladies Parasitaires, INRA, 37380 Nouzilly, France.

** Unité associée INRA/ENVN Interactions hôte-parasite-milieu, École Nationale Vétérinaire de Nantes, BP 40706, 44307 Nantes Cedex 03, France.

Correspondence: Omar Tliba.
}

Tel.: 0247427761 - Fax: 0247427774 - E-mail: tliba@tours.inra.fr
Résumé : RÉPONSE IMMUNITAIRE HÉPATIQUE LOCALE CHEZ LE RAT INFESTÉ EXPÉRIMENTALEMENT PAR FASCIOLA HEPATICA

L'objectif de cette étude était de caractériser la distribution des différentes cellules immunitaires et inflammatoires. Les souspopulations lymphocytaires (TCD4+ $4^{+}, \mathrm{TCD}^{+}, \mathrm{TCD} 43^{+}$et les cellules $\mathrm{lg}^{+}$), ainsi que les macrophages et les éosinophiles, associés aux lésions hépatiques et dans les ganglions lymphatiques ont été étudiés chez des rats infestés expérimentalement par Fasciola hepatica. Nous avons recherché la fixation des différentes isotypes d'immunoglobulines sur les douves en migration et comparé ces résultats avec la réponse humorale systémique. Dès la première semaine post infestation (SPI), les espaces portes hépatiques sont infiltrés par des cellules inflammatoires et immunitaires. Les cellules dominantes sont des éosinophiles et dans une moindre part, des macrophages et des lymphocytes (TCD4+, TCD8+ et B). La plupart de ces cellules n'atteignent que la partie postérieure du parasite, alors qu'elles sont moins nombreuses devant celui-ci. A l'exception des éosinophiles, aucune autre cellule ne pénètre dans le granulome constitué de nombreuses cellules hépatiques nécrotiques. On détecte les lgM dans le foie dès la ISPI, et avec une moindre intensité les lgA, $\lg G_{2 a}$ et les $\lg G_{2 b}$. A 2SPI les lgE et les $\lg G_{1}$ deviennent détectables, et enfin à la $3 S P I$ les $\lg G_{2 c}$. Au niveau des ganglions lymphatiques hépatiques, nous observons dans la zone corticale plusieurs follicules lymphoïdes microscopiques avec une prolifération des centres germinatits et des cordons medullaires. Le rôle protecteur des différentes cellules infiltrées et les différentes isotypes d'immunoglobulines, et les éventuels mécanismes d'échappement parasitaires vis-à-vis du système immunitaire sont discutés. 
tion with $F$. bepatica. In addition, humoral response and in particular specific immunoglobulin isotypes have been described in a number of natural or experimental hosts such as Rat (Poitou et al., 1992), Man (Pailler et al., 1990) and Sheep (Chauvin et al., 1995). The local immune response in the area surrounding young flukes during migration through the liver which may play a role in resistance mechanisms has been explored less. Chauvin et al., (1996) showed that the migratory tunnels produced by juvenile flukes in sheep liver appeared as focal areas of necrosis surrounded by infiltrating inflammatory cells, in particular numerous macrophages, eosinophils and $\mathrm{OvCD} 4^{+}$lymphocytes. Moreover, during chronic infection and re-infection in sheep, the number of $\mathrm{CD}^{+}$lymphocytes became greater than that of $\mathrm{CD}^{+}$(Meeusen et al., 1995). However, local immune cellular and humoral responses have not been studied in hepatic lesions and hepatic lymph nodes (HLN) of less susceptible hosts such as cattle or rats.

The aim of the present study was to describe, in rats, the localisation and kinetics of cellular responses (macrophages, eosinophils, lymphocyte subpopulations) and humoral responses (IgM, IgG subclasses, IgA and IgE) between WPI 1 and WPI 8 in the areas surrounding juvenile flukes and in the surrounding hepatic parenchyma. The immune response in HLN was also explored.

\section{MATERIALS AND METHODS}

\section{EXPERIMENTAL DESIGN}

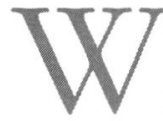

istar male rats (Iffa Credo, Arbresle, France) approximately 13 weeks old were used.

In this protocol, eight groups of two rats which were infected orally with 50 metacercariae, and one group of 12 rats (uninfected animals) were killed at regular intervals after infection. Group G1, G2, G3, G4, G6 and G8 were killed at 1, 2, 3, 4, 6 and 8 WPI, respectively. Two animals in the control group were necropsied at $0,1,2,3,4,6$ and 8 WPI. Dose effect was studied: G1.1, G1.2 and G1.3 were infected with 50, 100 and 200 metacercariae respectively.

\section{NECROPSY AND HISTOLOGICAL PREPARATION}

Rats were killed by chloroform inhalation. The livers and HLN were immediately removed. Several $1 \mathrm{~cm}^{3}$ samples of liver or HLN were dissected from the macroscopically visible lesions in each rat or from the control rat, embedded in OCT compound (Tissue-tek; Miles, USA) and rapidly immersed in isopentane cooled with dry ice. All samples were stored at $-80^{\circ} \mathrm{C}$ until further processing. For each animal, 7-8 $\mu \mathrm{m}$ thick sec- tions of six to ten liver samples and one HLN sample were serially sectioned using a cryostat (Rua, France), and air-dried overnight.

\section{STAINING}

Eosinophils and macrophages were identified on hemalun-eosin (HE) or May-Grünwald Giemsa (MGG) stained sections. Lymphocyte subpopulations and different immunoglobulin subclasses were characterised by immunohistochemistry with IgG1 mouse monoclonal antibodies (Mabs). All primary Mabs were purchased from Serotec (Argène Varilhes, France). Pan-T lymphocytes (CD $43^{+}$cells), TCD $4^{+}$lymphocytes, TCD $8^{+}$ lymphocytes and macrophages were identified using Mab W3/13 (1:50), Mab W3/25 (1:75), Mab OX-8 (1:30) and Mab ED2 (1:800) respectively. For the isotypes of immunoglobulins IgM, IgE, IgA, IgG $\operatorname{IgG}_{2 \mathrm{a}}, \operatorname{IgG}_{2 \mathrm{~b}}$ and $\operatorname{IgG}_{2 \mathrm{c}}$ we used, respectively, Mab MARM-4 (1:3000), Mab MARE-1 (1:400), Mab MARA-1 (1:400), Mab MARGE 1-2 (1:800), Mab MARGE 2-A61 (1:800), Mab MARG 2b-8 (1:800), and Mab MARGE 2c5 (1:400).

For immunohistochemical staining, we used the technique previously described by Cordell et al., (1984), modified by Pepin et al., (1992). Tissue sections were fixed in acetone at $-20^{\circ} \mathrm{C}$ for $10 \mathrm{~min}$, air dried for $20 \mathrm{~min}$ and rehydrated for $15 \mathrm{~min}$ with Tris-buffered saline (TBS, $0.05 \mathrm{M}$ Tris, $0.15 \mathrm{M} \mathrm{NaCl}, \mathrm{pH}$ 7.6). Sections were incubated with MAb for $30 \mathrm{~min}$ in a humid chamber. After three washes in TBS, sections were covered with a 1:100 dilution of rabbit anti-mouse Igs (depleted on rat Igs) (Dako, Denmark) for $30 \mathrm{~min}$ in a humid chamber. After washing three times in TBS, they were incubated with a 1:100 dilution of APAAP complex (soluble complexes of calf intestinal Alkaline Phosphatase and Mouse monoclonal Anti-Alkaline Phosphatase (Dako)) for $30 \mathrm{~min}$ in a humid chamber. After washing twice in TBS and twice in Tris $\mathrm{HCl} 0.1$ $\mathrm{M} \mathrm{pH} \mathrm{8.2,} \mathrm{the} \mathrm{slides} \mathrm{were} \mathrm{stained} \mathrm{with} \mathrm{the} \mathrm{filtered} \mathrm{sub-}$ strate: $20 \mathrm{mg}$ Naphtol AS-TR phosphate (Sigma, SaintLouis, USA), $2 \mathrm{ml}$ dimethylformamide (Prolabo), $30 \mu \mathrm{g}$ levamisole (Sigma), $100 \mathrm{ml}$ Tris-HCl $0.1 \mathrm{M} \mathrm{pH} 8.2$ and $100 \mathrm{mg}$ Fast Red TR salt (Sigma) for $20 \mathrm{~min}$. Slides were washed in water for $10 \mathrm{~min}$, counterstained with hematoxylin (Sigma) for 30 to $60 \mathrm{~s}$ and mounted in glycerol gelatine.

\section{RESULTS}

\section{HEPATIC PARENCHYMA}

Lesion description

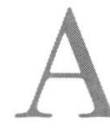
t necropsy, there were no appreciable lesions in the livers of control animals, neither macroscopically nor microscopically. In infected animals, numerous macroscopic, tortuous migratory path- 
ways began to be observed after the second week of infection. In groups G6 and G8, the livers presented irregular surfaces, with nodular and pale areas. The main bile duct appeared to be enlarged, wide and with flukes inside.

Microscopically, six juvenile flukes were observed in the hepatic parenchyma (in two animals at 1 WPI, in one animal at 2 WPI, in one animal at 3 WPI and in two animals at 4 WPI (Fig. 1a)). The most striking feature of the hepatic parenchyma concerned the numerous migratory tunnels formed by juvenile flukes (Figs. $1 b$ and $1 c$ ). Eosinophils invaded the center of these pathways (Fig. 1: arrow). They were the predominant cell type among the mononuclear cells, macrophages and neutrophils which accumulated near the necrotic hepatocytes. At 3 WPI we observed, likewise, pericholangitis and the beginning of periportal fibrosis (Fig. 1d). Bands of collagen of variable size linked the migratory tunnels to adjacent structures such as portal triads and hepatic veins. They subdivided the paren- chyma into a series of regular lobules. At 6 WPI, hyperplastic ductular epithelia associated with proliferating portal areas (Fig 1d) were observed. At 8 WPI, eosinophils and other inflammatory and immune cells spread into the surrounding parenchyma. We also observed the formation of batches of bile ductules (Fig. 1d). The size of these lesions increased during the infection and resulted in cirrhosis formation.

\section{Local cellular response}

In control animals, immunohistological staining showed that $\mathrm{T}$ lymphocytes and macrophages were distributed homogeneously throughout the hepatic parenchyma (Figs. $2 a, 2 c, 2 e$ ). In infected animals, microscopic examination showed that, as early as 1 WPI, the dominant cells were eosinophils (Fig. 1b). At this moment, immune and inflammatory cells and particularly T lymphocytes were found in small numbers in the area surrounding the parasite (Fig. 2f). There were fewer macrophages and lymphocytes than eosinophils, and
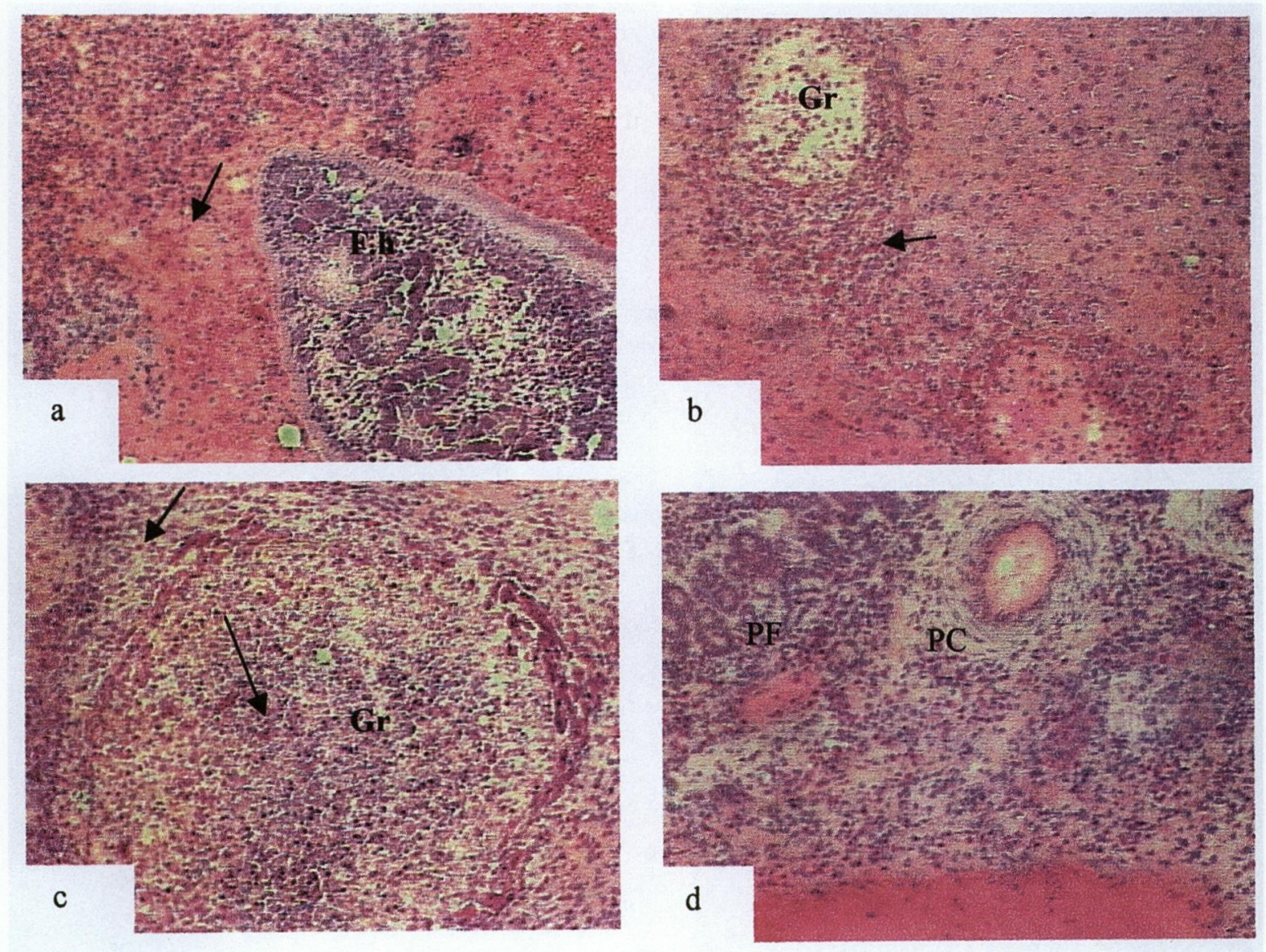

Fig. 1. - Haematoxylin/eosine stained frozen section showing:

(a) Liver flukes at 4 WPI $(\times 200)$;

(b) Granuloma at 1 WPI $(\times 200)$;

(c) Granuloma at 4 WPI $(\times 200)$;

(d) Hyperplastic ductular epithelium and bile ductules formation at 6 WPI $(\times 400)$.

Gr: granuloma; PC: pericholangitis; PF: periportal fibrosis; Arrow: eosinophils. 

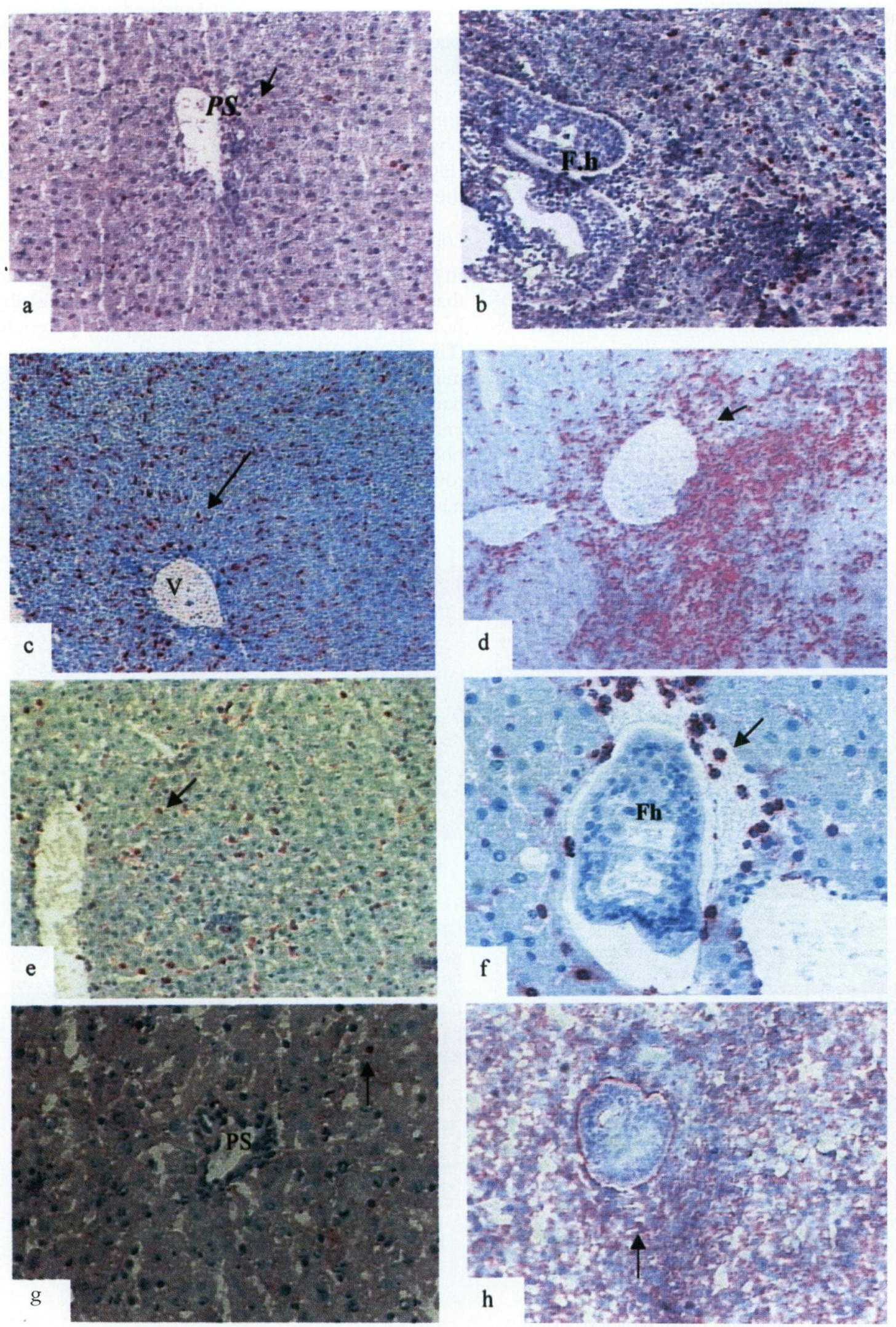

Fig. 2. - Immunohistology staining of frozen sections in hepatic parenchyma showing:

(a) TCD $8^{+}$in uninfected control animal $(\times 200)$, (b) TCD8 ${ }^{+}$at 2 WPI $(\times 200)$; (c) macrophage in uninfected control animal $(\times 100)$, (d) macrophage at 2 WPI $(\times 100)$; (e) TCD $43^{+}$in uninfected control animal $(\times 200)$, (f) TCD $43^{+}$at 1 WPI $(\times 400)$; $(\mathrm{g})$ IgM in uninfected control animal $(\times 200)$, (h) IgM at 1 WPI $(\times 200)$.

PS: portal space; F.h: Fasciola hepatica; V: centrolobular vein. 
their number increased clearly at 2 WPI (Figs. $2 d$ and $2 b$ ). As of 2 or 3 WPI, we noted an inflammatory infiltrate surrounding the juvenile flukes (Fig. $2 b$ ) which is was greater in the posterior part of the flukes. The granuloma was surrounded by an area of infiltrating inflammatory cells, particularly macrophages, lymphocytes $\left(\mathrm{CD}^{+}, \mathrm{CD}^{+}, \mathrm{CD}^{3} 3^{+}\right)$, eosinophils and a few neutrophils. We also found these cells in fibrosis. The structure of these granulomatous lesions was similar in all infected rats but their size increased from WPI 1 to WPI 8 (Table I). Some B lymphocytes ( $\mathrm{IgM}^{+}$cells) were observed in the inflammatory infiltrate in the area surrounding the juvenile flukes (Fig. $2 b$ ) and in the migratory tunnels. We also noted a decrease in the number of these cells in groups killed at 4, 6 and 8 WPI. Increasing numbers of parasites resulted in an increase in the recruited immune and inflammatory cells (group G1.1-G1.3) except for B cells which remained at a constant frequency.

\begin{tabular}{lccccc}
\hline Cells & TCD43 $^{+}$ & TCD4 $^{+}$ & TCD8 $^{+}$ & $\begin{array}{c}\text { Macro- } \\
\text { phage }\end{array}$ & (IgM $^{+}$cells $)$ \\
\hline Group C & + & + & + & + & + \\
Group G1 & ++ & ++ & ++ & ++ & ++ \\
Group G2 & +++ & +++ & +++ & +++ & +++ \\
Group G3 & +++ & +++ & +++ & +++ & +++ \\
Group G4 & +++ & +++ & +++ & +++ & + \\
Group G6 & +++ & +++ & +++ & +++ & + \\
Group G8 & +++ & +++ & +++ & +++ & + \\
\hline
\end{tabular}

Table I. - Cellular immune response in hepatic parenchyma. Number of stained cells per microscope areas was evaluated as follows: -: absence of staining; +: faint staining; ++ : medium staining; +++: intense staining).

\section{Local humoral response}

As early as 1 WPI, IgM could be detected in the liver (Figs. $2 b$ ), and to a lesser extent $\operatorname{IgA}, \operatorname{IgG}_{2 \mathrm{a}}$ and $\operatorname{IgG}_{2 \mathrm{~b}}$. At 2 WPI, IgE (Fig. $3 b$ ) and $\operatorname{IgG}_{1}$ began being detected. $\operatorname{IgG}_{2 \mathrm{c}}$ appeared at 3 WPI. The amount of detected antibodies (Ab) was directly correlated with the fluke burden.

All immunoglobulin isotypes exhibited a similar distribution. The staining intensity increased from 1 WPI to 8 WPI for IgM, IgA and $\operatorname{IgG}_{1}$ whereas $\operatorname{IgG}_{2 \mathrm{a}}, \operatorname{IgG}_{2 \mathrm{~b}}$ and IgE had decreased at $8 \mathrm{WPI}$. $\mathrm{IgG}_{2 \mathrm{c}}$ started to decrease at 6WPI. The plasma cells were found in the connective tissue or in the damaged parts of the liver. They were observed in the inflammatory infiltrate, in the granuloma lesions, in the area surrounding the parasites (Figs. $2 b, 3 d$ and $3 b$ ), in the portal tract and in the fibrotic strands (Fig. $3 f$ ). The tegument of juvenile flukes was covered by immunoglobulins of all isotypes except for IgE (Figs. $2 h, 3 d, 3 b$ ). The parasite caeca were also labelled but with less intensity than the tegument. We also noted that most of the IgE antibodies were bound to eosinophils (Fig. $3 b$ ).

\section{HEPATIC LYMPH NODES}

The HLN of infected animals exhibited numerous microscopic follicles in the cortical zone with proliferation of germinal centres and medullary cords (Figs. $4 a$, $4 b, 4 c, 4 d$ ). Hypertrophy of HLN was clearly observed as of 3 WPI.

Immunohistological staining showed that infiltration of immune and inflammatory cells in HLN and in hepatic parenchyma were related, the staining intensity increasing from 1 to 2 WPI, then being maintained throughout the infection. The majority of T lymphocytes (CD $43^{+}$, $\mathrm{CD}^{+}$and $\mathrm{CD}^{+}$) were located in follicles (Figs. $4 c, 4 d$ ) and in paracortical areas whereas moderate numbers of these cell subsets were located in the connective tissues of the medulla. Macrophages (ED2 ${ }^{+}$cells) were located especially in the follicle zone but also in the paracortical area and the medulla (not shown). B-lymphocytes ( $\mathrm{IgM}^{+}$cells) were observed in lymphoid follicle centres (Fig. 4b). The plasma cells were found on the border of the germinal centres and in large numbers in the medullary cords and the medulla. Numerous eosinophils were also present in the medulla but to a lesser extent than in the hepatic parenchyma. Staining of all immunoglobulin isotypes was generally greater at 2 WPI and remained throughout the infection, except for $\operatorname{IgG}_{2 \mathrm{c}}$ which decreased at 6 WPI.

\section{DISCUSSION}

The hyperplasia of lymphoid follicles and medullary cords of the HLN and the intense infiltration of leukocyte and immune cells in hepatic lesions indicated strong local immune reaction against the parasite.

The cellular response was characterised by extensive inflammatory infiltrate in hepatic lesions in the areas surrounding the parasites and migratory tunnels, and took place at 2 WPI. This infiltrate contained $\mathrm{T}$ and B lymphocytes, macrophages and numerous eosinophils. During the first week, the infiltrate was not oberved to be in contact with the juvenile flukes, suggesting that, early on in the infection, cellular responses did not reach the parasite. This enabled the parasite to migrate unhindered through the liver tissue. At 2 WPI, most of the immune cells were detected in the hinder part of flukes, whereas there were fewer of these cells in front of the parasite, which is consistent with other studies: in sheep liver, Chauvin et al., (1996) showed juvenile flukes migrating into healthy tissue. This suggests that liver flukes escape from the immune response which is developed behind them. 

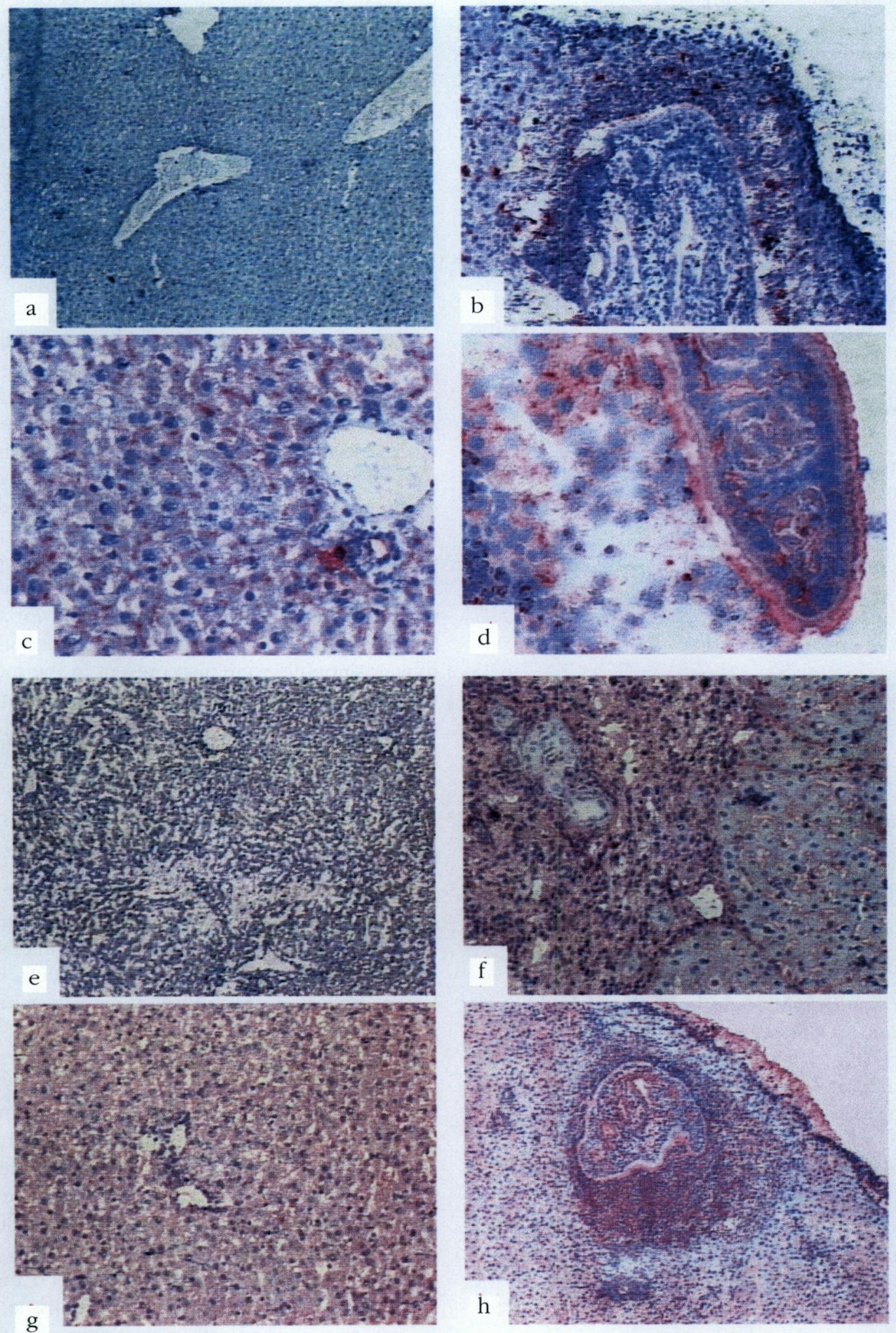

Fig. 3. - Immunohistology of frozen sections in hepatic parenchyma showing:

(a) IgE in uninfected control animal $(\times 100)$ and (b) at 2 WPI $(\times 200)$;

(c) IgA in uninfected control animal $(\times 400)$ and $(d)$ at 4 WPI $(\times 200)$;

(e) $\mathrm{IgG}_{1}$ in uninfected control animal $(\times 100)$ and (f) at 8 WPI $(\times 200)$;

(g) $\mathrm{IgG}_{2 \mathrm{a}}$ in uninfected control animal $(\times 200)$ and $(\mathrm{h})$ at 2 WPI $(\times 100)$. 

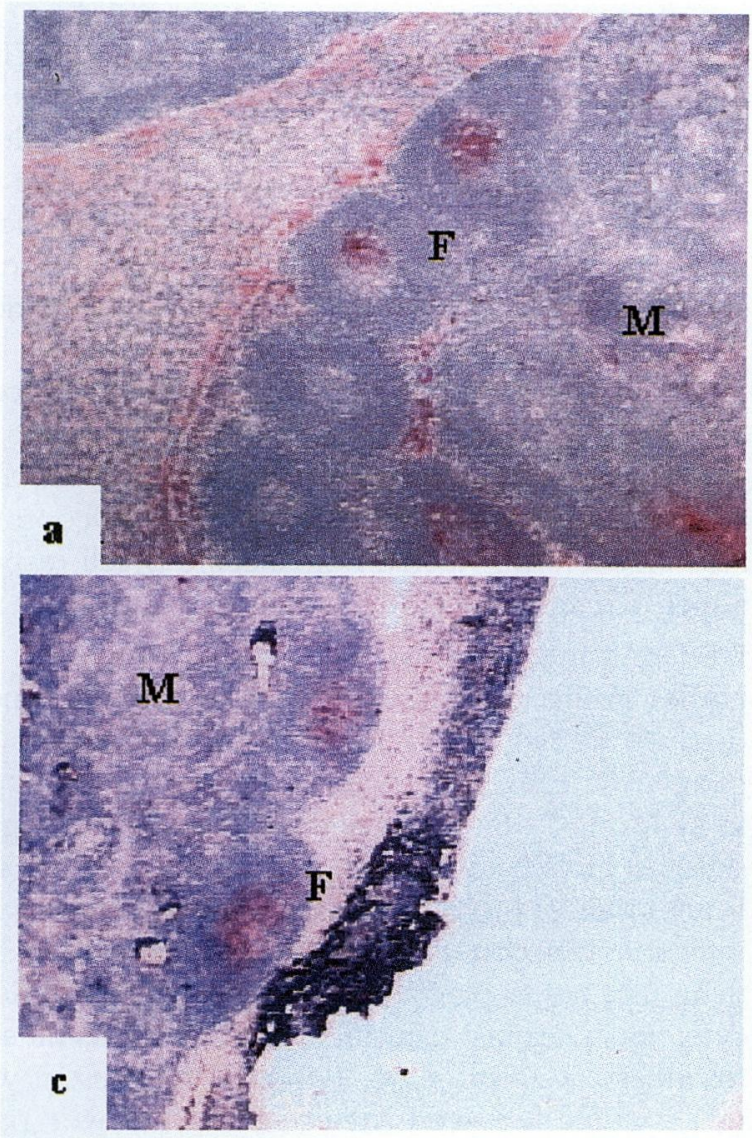

Fig. 4. - Immunohistology of frozen sections in hepatic lymph node: (a) IgA at 2 WPI ( $\times 100)$; (b) IgM at 2 WPI $(\times 100)$;

(c) $\mathrm{CD}^{+}$at 2 WPI $(\times 100)$; (d) $\mathrm{CD}^{+} 3^{+}$at 2 WPI $(\times 100)$.

F: follicle; M: medulla.

Granuloma structure could be observed in the migration pathway behind the flukes. This local immune response was characterised by the infiltration of only eosinophils into the granuloma and also around the flukes. Conversely, an increase in $\mathrm{T}$ cells, B cells, macrophages and eosinophils was observed in the areas surrounding these migratory tunnels. This cell distribution was similar to the description given by Chauvin et al., (1996) in sheep liver during experimental infection with $F$. hepatica. Baéza et al., (1994) noted an early reduced systemic inflammatory response during the first two weeks in rats infected with $F$. hepatica, suggesting impairment of the host defence mechanisms by the flukes. Moreover, $F$. hepatica may avoid inflammatory responses by means of rapid migration through healthy parenchyma (Chauvin et al., 1996).

The formation of pronounced peri-lobular fibrosis and the presence of large numbers of $\mathrm{CD}^{+}$cells in the fibrotic strands after 8 WPI were features of chronic infection in response to continuous stimulation with antigen. This was confirmed by the persistence of lymphoid follicles in the HLN at 8 WPI. Masake et al.,
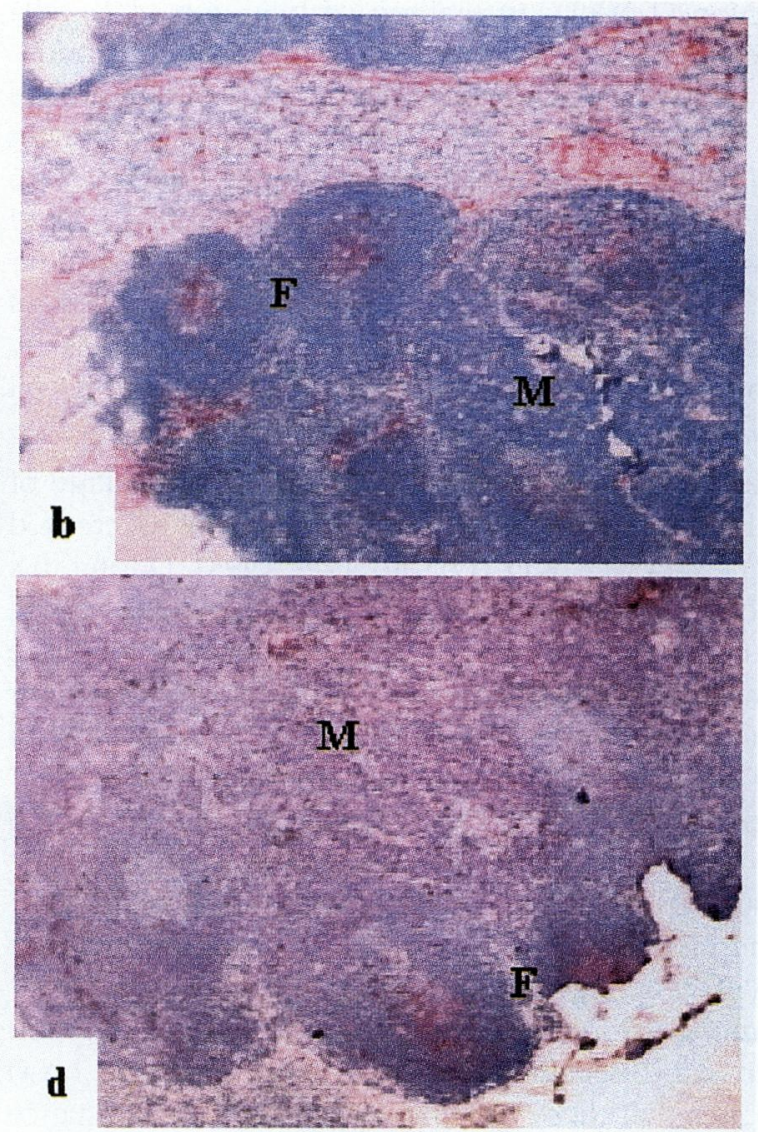

(1978) showed, in mice experimentally infected with $F$. hepatica, that the regeneration of damaged liver cells was completed two months after infection, although hyperplasia persisted in bile ducts containing flukes. A similar observation was noted in our study; at 8 WPI, except for the lesion areas which turned to cirrhosis, the livers looked healthy, in contrast with the totally damaged livers observed at 4 WPI.

The local cellular response appeared to be dosedependent. Inflammation intensity increased with parasite burden, indicating that the local immune response was dependent on fluke number. This response increased from 1 WPI to 8 WPI, which may have been due to increasing amounts of released excretion-secretion (ES) antigens and the number and size of lesions in the liver.

Local immune responses may be correlated with systemic immune responses. Poitou et al., (1993) observed a significant increase in numbers of B lymphocytes in the spleen of experimentally infected rats from 3 WPI to 7 WPI. This was correlated with $i$ ) the development of lymphoid follicles, particularly in HLN early after 
infection (1 WPI), ii) marked mobilisation of $\mathrm{B}$ cells in hepatic parenchyma (1 WPI), and iii) high production of various different $\mathrm{Ab}$ isotypes observed in the liver and serum. In sheep, the observations of Chauvin et al. (1996) were similar. In addition, Poitou et al., (1993) showed systemic eosinophilia which correlated with the early and intense local eosinophilic infiltration also observed in this study. This eosinophil recruitment could be caused by eosinophil chemotactic factors (ECF) detected in $F$. hepatica ES products (Horii et al., 1986).

During experimental rat fasciolasis, the percentage of circulating $\mathrm{CD}^{+}$and $\mathrm{CD}^{+} \mathrm{T}$ lymphocytes decreased from 1 WPI to 8 WPI (Poitou et al., 1993). During this period, in liver parenchyma, $\mathrm{CD}^{+}$and $\mathrm{CD}^{+}$cell recruitment increased in the area surrounding the fluke migration pathways and this could explain why their numbers decreased in the blood. In sheep, Moreau (1997) also showed that circulating $\mathrm{CD}^{+}$and $\mathrm{CD}^{+}$ T lymphocytes decreased during fasciolasis between 3 and 6 WPI. However, in sheep liver, Chauvin et al. (1996) observed an increase in the number of $\mathrm{CD}^{+}$ T-lymphocytes, and no increase in the number of $\mathrm{CD}^{+}$T-lymphocytes. This difference observed in $\mathrm{CD}^{+}$ T-lymphocyte recruitment in hepatic parenchyma between rat (resistant host) and sheep (sensitive host) indicates that these cells may play a role in resistance to the parasite.

Among the most important features of the local humoral responses, we observed a high level of IgM, which correlates with systemic humoral response previously described in the rat (Poitou et al., 1993; Wedrychowicz et al., 1987) and in sheep fasciolosis (Chauvin et al., 1995). IgM antibodies are an indicator of a primary response against an antigen (Takahashi et al., 1990). The persistence, during the entire course of infection, of a high level of IgM covering the fluke tegument might be explained by the sequential secretion of different parasite antigens (Poitou et al., 1992), by a rapid turnover of the outer glycocalyx of the flukes (Hanna et al., 1980a; Duffus et al., 1980), or by a high level of B cells stimulation by carbohydrate epitopes. Glauert et al., (1985) suggest that, as eosinophils do not express Fc $\mu$ receptor (McEwen et al., 1992), this IgM deposition on fluke tegument may inhibit eosinophil access to the parasite. The same IgM responses were noted in other hosts such as sheep (Chauvin et al., 1996) and to other trematodes such as Schistosoma mansoni (Khalif et al., 1985). Thus IgM may act as a blocking isotype during fasciolasis.

Another blocking isotype observed in this study is $\mathrm{IgG}_{2 \mathrm{c}}$. This antibody has been described as a blocking factor in immunity to schistosome and in particular in $\mathrm{IgG}_{2 \mathrm{a}}$-mediated eosinophil cytotoxicity (Khalif et al., 1985). The authors suggested that the existence of a common receptor shared between $\mathrm{IgG}_{2 \mathrm{c}}$ and $\mathrm{IgG}_{2 \mathrm{a}}$ on the eosinophil surface could be the cause of this blocking effect. In this study, $\operatorname{IgG}_{2 c}$ antibody was also detected at the third WPI in hepatic parenchyma and in HLN, suggesting that $F$. bepatica may enhance ineffective humoral responses by two different mechanisms: one involving IgM which coat the parasite and avoid ADCC (Antibody dependent cellular cytotoxicity), the second involving $\operatorname{IgG}_{2 c}$, inducing competitive blocking of $I g G_{2 a}$ receptors on the eosinophil surface. In addition, these antibodies are known to react with T-cell independent antigens (Der Balian et al., 1980) such as carbohydrate molecules. These glycoproteins also induce a polyclonal non specific $\mathrm{B}$ cell response which blurs the specific immune response.

$\operatorname{IgG}_{2 \mathrm{a}}$ and $\mathrm{IgE}$ are considered to be anaphylactic antibodies in the rat (Capron et al., 1977). These antibodies are known to be involved in cooperation with phagocytic cells such as macrophages or eosinophils in ADCC. $I_{g G_{2 a}}$ monoclonal antibodies directed against schistosomula have been shown to confer highly significant levels of protection against Schistosoma mansoni infection (Capron et al., 1983). IgE has also been demonstrated to play a pre-eminent role in eosinophil cytotoxicity against parasitic diseases such as rat schistosomiasis (Capron et al., 1981). In the present work, $\mathrm{IgG}_{2 \mathrm{a}}$ antibodies were detected in the liver parenchyma and in HLN as early as 1 WPI. IgE antibodies appeared in the hepatic parenchyma at 2 WPI, suggesting that $F$. bepatica also induces an effective humoral response by producing two effector antibodies, $I g G_{2 \mathrm{a}}$ and $\mathrm{IgE}$, which may play a protective role in fasciolosis depending on the balance between protective and antagonist antibodies.

Among other antibodies which may play a protective role in disease, $\operatorname{IgG}_{1}$ antibodies are involved in effector mechanisms of acquired resistance and schistosome killing (Capron et al., 1977), $\operatorname{IgG}_{2 \mathrm{~b}}$ antibodies have lethal activity towards schistosoma in vitro in the presence of complement (Fatima et al., 1984), and IgA antibodies are involved in mechanisms implying eosinophils conferring protection against schistosoma (Grezel et al., 1993). Van Milligen et al., (1998), demonstrated that, upon challenge of immune rats with $F$. bepatica in an ex vivo gut segment, new excysted juvenile flukes that migrated through the mucosa were coated with $\operatorname{IgG}_{1}$ and $\operatorname{IgG}_{2 \mathrm{a}}$ antibodies and surrounded by eosinophils, which correlated with the expression of protection, suggesting that juvenile flukes are killed by eosinophil-mediated cytotoxic response involving IgG antibodies. In rat liver, the role of these antibodies has not been explored.

In rat fasciolosis, further studies are needed to explore the role of the parasite in regulating the host immune response. Particularly, different cytokines secreted by 
lymphocytes and other immune cells in blood, hepatic parenchyma and HLN seem to be important in determining parasite rejection or maintenance. The role of $F$. hepatica in the differentiation of $\mathrm{T}$ lymphocytes should be further investigated.

\section{ACKNOWLEDGEMENTS}

W e are grateful to Florence Carreras for providing metacercariae and to Jacques Auger for rat handling.

\section{REFERENCES}

BaÉza E., Poitou I. \& Boulard C. Influence of pro-inflammatory treatments on experimental infection of rats with Fasciola bepatica: changes in serum levels of inflammatory markers during the early stages of fasciolasis. Research in Veterinary Science, 1994, 57, 180-187.

Boulard C., Bouvry M. \& Argente G. Comparaison de la détection des foyers de fasciolose par test ELISA sur lactoserum et serum et par coproscopie. Annales de Recherche Vétérinaire, 1985, 16, 363-368.

CAPRON A., DESSAINT J. P. \& CAPRON M. Effector mechanism in immunity to schistosomes. Immunity in parasite diseases. Les colloques de l'Institut National de la santé et la recherche médicale, 1977.

Capron M., Bazin H., Joseph M. \& Capron A. Evidence for IgE dependent cytotoxicity by rat eosinophils. Journal of Immunology, 1981, 126, 1764-1768.

Capron M., Capron A., Abdel Hafez S. K., Bazin H., Joseph M. \& PHILIPs, S.M. Immunologic response of athymic rats to Schistosoma mansoni infection. II. Antibody-dependent mechanisms of resistance. Journal of Immunology, 1983, 131, 1475-1480.

Chauvin A., Bouvet G. \& Boulard C. Humoral and cellular immune responses to Fasciola bepatica experimental primary and secondary infection in sheep. International Journal of Parasitology, 1995, 25, 1227-1241.

Chauvin A.\& Boulard C. Local immune response to experimental Fasciola bepatica infection in sheep. Parasite, 1996, 3, 209-215.

Cordell J., Falini B., Erbr W.N., Ghosh A. K., Abdulaziz Z., MacDonald S., Pulford K.A., Stein H. \& Mason D.Y. Immunoenzymatic labelling of monoclonal antibodies using immune complexes of alkaline phosphatase and monoclonal anti-alkaline phosphatase (APAAP complexes). Journal of Histochemisrty and Cytochemistry, 1984, 32, 219229.

Der Balian G. P., Slack J., Clevinger B.L., Bazin H. \& Davies J.M. Subclass restriction of murine antibodies. III. Antigens that stimulate IgG3 in mice stimulate IgG2c in rats. Journal of Experimental Medicine, 1980, 152, 209-218.

Duffus W.P.H. \&. Franks D. In vitro effect of immune serum and bovine granulocytes on juvenile Fasciola bepatica.
Clinical and Experimental Immunology, 1980, 41, 430440.

Fatima M., Horta M. \& Juarez Ramalho-Pinto F. Subclasses of rat IgG active in the killing of Schistosoma mansoni in vitro and in vivo. Journal of Immunology, 1984, 133, 33263332.

Glauert A.M., Lammas D.A. \& Duffus W.P. Ultrastructure observation on the interaction in vitro between bovine eosinophils and juvenile Fasciola hepatica. Parasitology, 1985, 91, 453-470.

Grezel D., Capron M., Grzych J.M., Fontaine J., Lecoce J.P. \& CAPRON A. Protective immunity induced in rat schistosomiasis by a single dose of the Sm28GST recombinant antigen: effector mechanisms involving IgE and IgA antibodies. European Journal of Immunology, 1993, 23, 454460 .

Hanna R.E.B. Fasciola hepatica: glycocalyx replacement as a possible mechanism for protection against host immunity. Experimental Parasitology, 1980, 50, 103-114.

Horit Y., FujtTa K. \& Owhashi M. Partial purification and characterization of eosinophil chemotactic factors from soluble extract of Fasciola hepatica species. American Journal of Veterinary Research, 1986, 47, 123-126.

Khalife J., Capron M., Grzych J.M., Bazin H., \& Capron A. Fc gamma receptors on rat eosinophils: isotype-dependent cell activation. Journal of Immunology, 1985, 135, 27802784 .

Masake R., Wescott R.B., Spencer G.R. \& Lang B.Z. The pathogenesis of primary and secondary infection with Fasciola bepatica in mice. Veterinary Parasitology, 1978, 15, 763769.

McEwen B.J. Eosinophils: a review. Veterinary Research Communications, 1992, 16, 11-44.

Meeusen E., Lee C.S., Rickard M.D., \& Brandon M.R. Cellular responses during liver fluke infection in sheep and its evasion by the parasite. Parasite Immunology, 1995, 17, 3745 .

MOREAU E. Interactions lymphocytes-antigènes parasitaires au cours de la fasciolose à Fasciola hepatica Linnée, 1758, chez le mouton. Paris, Paris XII-Val De Marne (1997).

Oldham G. Immune responses in rats and cattle to primary infections with Fasciola hepatica. Research in Veterinary Science, 1985, 39, 357-363.

Pailler S., Puygauthier-Taubas D., Bonnin A., Marx-Chelma C., Camerlynk P., Thoannes H. \& Pinon J.M. Caractérisation isotypiques des anticorps spécifiques dans la distomatose humaine à Fasciola hepatica. Médecine et Maladies Infectieuses, 1990, 20, 177-181.

Pepin M., Cannella D., Fontaine J., Pittet J.C. \& Le Pape A. Ovine mononuclear phagocytes in situ: identification by monoclonal antibodies and involvement in experimental pyogranulomas. Journal of Leukocyte Biology, 1992, 51, 188-198.

Poitou I., BaÉza E. \& Boulard C. Humoral and cellular immune responses in rats during a primary infestation with Fasciola bepatica. Veterinary Parasitology, 1992, 45, 5971 
Poitou I., BAÉzA E. \& Boulard C. Kinetic responses of parasite-specific antibody isotypes, blood leukocyte pattern and lymphocyte subsets in rats during primary infestation with Fasciola hepatica. Veterinary parasitology, 1993, 49, 179190.

Takahashi Y., Mizuno N., Uno T., Aisaka A. \& Araki T. A spectrum of antibody response with time after Trichinella spiralis infection in rats. Journal of Parasitololgy, 1990, 76, 230-239.

Van Milligen F.J., Cornelissen J.B., Hendriks I.M., GaAsenBEEK C.P. \& BOKHOUT B.A. Protection of Fasciola hepatica in the gut mucosa of immune rats is associated with infiltrates of eosinophils, $\operatorname{IgG}_{1}$ and $\operatorname{IgG}_{2 \mathrm{a}}$ antibodies around the parasites. Parasite Immunology, 1998, 20 (6), 285-292.

Wedrychowicz H. \&. Turner K. Antibody istoypes involved in local and systemic humoral responses of rats to primary and secondary infection with Fasciola bepatica. Acta Parasitologica Polonica, 1987, 32, 369-389.

Reçu le 23 février 1999 Accepté le 8 novembre 1999 